\title{
Sådan søger man om optagelse i Scopus og Web of Science
}

\section{Journal title submission to Scopus}

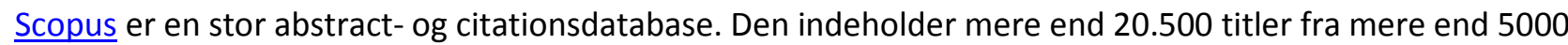
internationale udgivere. I alt dækker den over mere end 19.500 peer-reviewed tidsskrifter, heraf 1900 Open Access tidsskrifter. Derudover er der 360 bog-serier og over 5 mio. konferenceartikler i proceedings og tidsskrifter. Scopus dækker alle hovedområder.

For at et tidsskrift kan blive indekseret i Scopus, er der visse kriterier der skal være opfyldt. Disse vil blive listet i nedenstående. En uafhængig redaktion hos Scopus, Content Selection \& Advisory Board (CSAB), vurderer alle tidsskrifter, inden de bliver indekseret.

Minimumskrav:

- Tidsskriftet skal udgive peer reviewed indhold

- Tidsskriftet udgives regelmæssigt (dvs. have et ISSN som er registreret hos the International ISSN Centre)

- Tidsskriftet skal have et engelsksproget abstrakt og artikeltitler

- Referencer skal skrives i det latinske alfabet

- Tidsskriftet skal have en publiceringsetik og en erklæring vedrørende uredelig publicering (eksempelvis fra Committee on Publication Ethics (COPE) og World Association of Medical Editors (WAME))

Nye titler vurderes hurtigst muligt, men der kan gå flere måneder og op til et år, før processen er færdig.

Det anbefales at et tidsskrift har været publiceret i mindst to år, før man indsender det til vurdering ved Scopus.

Kriterier, der er en fordel at have:

- Tidsskriftet er i stand til at nå ud til nye målgrupper og sikre en høj kvalitet af forfatterskab

- Tidsskriftet er understøttet af en udvælgelsesproces med klare anbefalinger og kriterier for kvalitet

- Tidsskriftet kan benchmarkes med konkurrerende tidsskrifter i forhold til kvalitet

Et tidsskrifts kvalitet er defineret ved:

- Ensretning i forhold til den etablerede "best publication industry practice" $\mathrm{i}$ forhold til formatering

- Ensretning i forhold til den etablerede "best publication ethics and malpractice practice"

- Originalitet i forhold til overvejelser og indhold

- Indholdet er troværdigt og pålideligt

- Indholdet er anvendeligt/nyttigt for en specialiseret eller generel læserskare 
- Tidsskriftets indhold er nemt tilgængeligt for det fællesskab, det skal tjene

Tidsskriftets ultimative kvalitetsmål inkluderer:

- Dets varighed

- Dets formåen i forhold til at tiltrække og publicere manuskripter, reviewers, forfattere og læsere

- Dets finansielle overlevelsesmuligheder

- Målgruppens og andre forskeres brug af indholdet

Dette kigger CSAB efter i forhold til:

Varighed/overlevelsesmuligheder:

- Dokumentation af publikationer og citationer fra mindst 2 år, helst længere tid

- Bevis for konsistensen og hyppigheden af rettidig publicering

- Bevis for en fornuftig mængde materiale per nummer. Hvor online tidsskrifter publiceres på års basis, kigger de efter det årlige flow af indhold

Publiceringssprog:

- Tidsskrifterne skal have et engelsk abstrakt af indholdet, helst for hver artikel

- De opfordrer til at tidsskrifterne overvejer at stille engelsksprogede fuldtekst oversættelser til rådighed på deres hjemmesider, hvis ikke i papirudgivelserne, for at hjælpe forfatterne med at nå ud til et bredere publikum.

Tidsskriftets hjemmeside:

- De opfordrer til at redaktører og udgivere kigger på deres hjemmesider og overvejer om de kommunikerer tidsskriftet og dets indhold på den mest effektive måde

- Editorial Board medlemmer

- Formål og virkefelt

- Udgiver

- Publication Ethics and Malpractice

Institutionelle tidsskrifter kan blive valgt fra da:

- Deres primære formål er at være et repository for institutionen og tærsklen for kvalitet er derfor relativ lav

- De dækker et bredt område af emner

- De mangler det konkurrerende gåpåmod til at udvælge artikler, der kan nydes af et "widely sourced journals"

- De har et begrænset antal forfattere

Bred indholdsdækning versus specialisering:

- Det kan være en fordel med emnespecialisering idet det:

o Definerer en forfattermålgruppe

o Definerer en publikumsmålgruppe 
o Fokuserer på den måde redaktørerne og udgiverne tænker

Valg af meningsfuld tidsskriftstitel:

- De opfordrer til at titlen reflekterer så nøjagtigt som muligt tidsskriftets specifikke hensigt såvel som dets internationale eller regionale/nationale retning

\section{Journal title submission to Web of Science}

Web of Science (WoS) er en citationsdatabase, som indeholder mere end $12.000 \mathrm{~h} \varnothing \mathrm{jt}$ rangerede tidsskrifter, som også inkluderer Open Access tidsskrifter samt mere end 150.000 konference proceedings. Indholdet er nutidigt, men der findes også ældre tidsskrifter. WoS dækker over alle fagområder.

For at blive indekseret i WoS, skal en redaktion hos Thomson Reuters først vurdere tidsskriftet. Redaktionerne er sammensat efter fagområde, og alle i redaktionen er højtuddannede lige netop inden for det område, som de skal vurdere i forhold til. Der er forskellige kriterier for at blive optaget, som vil blive beskrevet i nedenstående.

Tidsskrifterne vurderes i forhold til:

- Tidsskriftets publiceringsstandard

o Rettidighed. Det er essentielt at tidsskriftet udgives rettidigt og med den anførte frekvens

o Ved elektroniske tidsskrifter, som nogle gange publicerer enkelte artikler, kigges der på om der er en stabil strøm af disse over en periode

o Informativ titel

o Deskriptive artikeltitler og forfatterabstracts

o Komplette bibliografiske informationer om de citerede referencer

o Komplette adresseinformationer for alle forfattere

o Fokus på tidsskrifter med fuldtekst på engelsk eller i det mindste bibliografiske informationer på engelsk

o Referencer skal stå med det latinske alfabet

o Tidsskriftet skal have en peer review-proces

- Det redaktionelle indhold

o Kun indhold, der vil bidrage med nyt til Web of Science

- International mangfoldighed

o International mangfoldighed blandt tidsskriftets forfattere, redaktører og det redaktionelle advisory board

o Et mindre antal regionale tidsskrifter vurderes

- Citationsdata

o Måler tidsskriftets citation impact

o Der tages højde for videnskabers forskellige citationskulturer

o Ved nye tidsskrifter som ikke har modtaget mange citationer, kigges der på forfatternes og redaktørernes citation record 


\section{Andelen af tidsskriftets selvcitationer vurderes}

Indsendelsesprocedure:

- De seneste tre numre indsendes, én af gangen efterhånden som de bliver publiceret

- Der kan indsendes både print eksemplarer, online eksemplarer eller begge dele

- Print eksemplarer sendes til følgende adresse:

Publication Processing, Thomson Reuters, 1500 Spring Garden Street, Fourth Foor, Philadelphia, PA 19130

- Online eksemplarer indsende ved brug af en formular som kan hentes på: http://science.thomsonreuters.com/info/journalsubmission/

- Udgivere og redaktører skal blive ved med at indsende tidsskriftets numre indtil evalueringsprocessen er færdig

Elektroniske tidsskrifter - $f ø l g e n d e$ elementer skal være nemme at identificere:

- Tidsskriftets titel

- Publikationsår

- Årgang (volume) og/elller nummer (issue)

- Artiklens titel

- Sidetal eller artiklens nummer (en af disse er påkrævet. Artiklens nummer er IKKE DOI). Hvis tidsskriftet både har sidetal og artikelnummer skal de listes separat og ikke sammenskrives (ex. Article No. 23, pp. 6-10 og IKKE 23.6-23.10)

- Forfatternes navn og adresse

- Markering af artiklens identifikator, såsom DOI, PII og artiklens nummer

- En komplet indholdsfortegnelse for hvert nummer som indeholder sidetal/artikelnummer for hver artikel (medmindre tidsskriftet publicerer enkeltartikler)

- Artikler skal have et unikt sidetal eller artikelnummer i hvert enkelt nummer

- Artikelnumre skal være unikke indenfor en årgang - undgå artikelnummer-dubletter

- Overvej at instruere forfattere i at citere tidsskriftet korrekt ved at de skal inkludere følgende informationer:

o Tidsskriftets titel

0 Årgang (volume)

o Nummer (issue) - hvis muligt, i parentes

o Sidetal og/eller artikelnummer

o Publikationsår 